$A D D I N$, Volume 12, Number 1, February 2018

\title{
SALAAM GREETING TO SPREAD PEACE IN THE ARCHIPELAGO OF INDONESIA
}

\author{
Nesia Andriana \\ Ibn Khaldun University, Bogor, Indonesia \\ nesiari@gmail.com
}

\section{Abstract}

Maintaining peace in the world has always been a noble aim, yet it remains an endless polemic. The archipelago of Indonesia, known as Nusantara, is home to more than 600 ethnic groups and if it is not well organized, it can lead to conflicts. This study aims to examine Islamic values, especially those conveyed in the hadeeths of Saheeh Bukhari, the Chapter on Seeking Permission. The focus of this study is to examine the relevant hadeeths to identify the pillars that Muslims can use to build and nurture peace in the archipelago. This research is conducted throughliterature review approach. The content of the hadeethsis associated with events that occurred in Nusantara, both in the era of independence and in the era of reform to reveal the potentials of Muslims as a majority, to maintain peace and unity throughout the archipelago. The study reveals that the saheeh hadeeths related to greeting of salaam and its rules contain the basic pillars that can contribute to sustaining peace in the archipelago. These pillars ensure the security and safety of individuals' privacy, public comfort, prevention of riots and conflicts, news monitoring, and maintain bumanitarian values to always promote peace in stead of hostility. These values are 
still embraced in general by Muslims in the archipelago. The Muslims still observe the principles of Bhineka Tunggal Ika and Pancasila, which are key to maintain peace and unity of the homeland.

Keywords: Islam, Nusantara, Muslim Civilization, Hadeeth, Peace, Union.

\section{A. Introduction}

Indonesia is the largest archipelagic country in the world with a total area of 7.81 million $\mathrm{km} 2$ with 17,499 islands. ${ }^{1}$ The Central Bureau of Statistics in cooperation with Southeast Asean Studies in 2013 mapped out the number of tribes in the archipelago, and it was found that this vast area is home to about 633 major ethnic groups. ${ }^{2}$ This amount is certainly very large and it cancouse problems if not managed wisely and properly.

History shows that in countries or places where Muslims are the majority, there has hardly occurred oppression or cruelty committed by Muslim community against minority groups. Indeed, in Islamic teaching, oppression by a majority against minority is unacceptable for any reasons. Tim Wallace Murphy saysthat history has proved that different from other regions, Islam has never oppressed other groups when it is in power. Under the power of Islamic state, people of other religions or minority groups could lived in harmony with Muslim majority. ${ }^{3}$ Similarly, Dudung Abdurrahman, states that although during the Umayyah period the dominance of

\footnotetext{
${ }^{1}$ Warta BPHN, Sumber: http://bphn.go.id/news/2015102805455371 /INDONESIA-MERUPAKAN-NEGARA-KEPULAUAN-YANGTERBESAR-DI-DUNIA, diakses pada 10 Januari 2018.

${ }^{2}$ Badan Pusat Statistik, Sumber: https://www.bps.go.id/ news/2015/11/18/127/mengulik-data-suku-di-indonesia.html , diakses pada 10 Januari 2018.

${ }^{3}$ Tim Wallace Murphy, What Islam Did for Us, Understanding Islam's Contribution to Western Civilization, London: Watkins Publishing, 2006, p. 2
} 
Arabia with all its culture and traditions was very strong, the rulers did not dispel or oppressed non-Arab groups. Moreover, in the Abasiyyah ruling, the rulers built civilisation in various aspects, such as science, ethics, government, art, on the basis of multicultural society. ${ }^{4}$

Ramadan al-Buthy describes the Arabian Peninsula before the coming of Islam as an area with a very backward society. Tribal fanaticism was so entrenched that discord among the tribes is part of their hard-to-remove ways of life. ${ }^{5}$ Islam then came and became a solution to various social problems of the Arab society at the time.

Graham E. Fuller outlined the phenomenon of oppression that takes place in other societies that became the majority.Fuller cites examples of atrocities committed by Hindu leaders of Hindutva groups against Muslims, Sikhs, as well as Christians; also Buddhist against Hindu Tamils in Sri Lanka. ${ }^{6}$ The issues of terrorism that are often associated to Muslims are described by Tim Wallace Murphy as mislabeling Islam. Fuller argued that terrorist movementsemergedas a result of western dominance and its pressure against other groups, and the movements have not only been established bygroups which attach themselves to Islam, but also by other groups. ${ }^{7}$

In Agung Wicaksono's view, the educational paradigm in Indonesia seems to be centralistic and tends to ignore the diversity of the nation. This can be seen from the emergence of disputes and hostilities that fueled ethnic and

${ }^{4}$ Dudung Abdurrahman, "Multiculturalism in Islamic Civilization During the Classic Period", Addin, Jurnal Sekolah Tinggi Agama Islam Negeri Kudus, Vol. 11, No. 1, February 2017, p. 49-50. DOI: http://dx.doi.org/10.21043/addin.v11i1.2071

${ }^{5}$ Muhammad Said Ramadhan Al-Buthy, Fiqh as-Sirah an-Nabawiyah Ma'a Mujaz. Litârîkh al-Khilâfah al-Râsyidah, Damaskus: Dâr al-Fikri, 1991, p. 46.

${ }^{6}$ Graham E. Fuller, A World Without Islam, New York: Back Bay Books, 2012, p. 48.

${ }^{7}$ Graham E. Fuller, A World Without Islam, pp. 335-345. 
cultural differences between regions. ${ }^{8}$ Sukoco mentions Sampit events as an example. According to him, one of the causes of inter-group disputes that occurred in the archipelago was social inequality. In line with this, Akhmad Hidayatullah Al Arifin concluded that multicultural-based education to spread peace is still counted as a new discourse in the archipelago. ${ }^{9}$ According to Egi Sukma Baihaki, the values contained in Bhineka Tunggal Ika need to be well managed in order to address pluralism in the archipelago. ${ }^{10}$

This study aims to reveal the potentials of Muslims as the majority in maintaining peace in the archipelago. The focus of the discussion is the saheeh hadeeths related to greeting of salaam and its rules, as well as the values contained therein which can contribute greatly to the maintainance of peace.

\section{B. Discussion}

\section{Meaning and role of Salam}

The Indonesian wordsalaam means peace or a statement of respect, or a short form of utterance of assalamu alayikum warahmatullahi wa barakatuh. ${ }^{11}$ Bersalaman meansgreeting to each

${ }^{8}$ Juniaris Agung Wicaksono, "Konsep Pendidikan Multikultural dalam Kebijakan Publik di Indonesia", An-Nuha, Jurnal Sekolah Tinggi Agama Islam Madiun, Vol. 3 No. 1, Juli 2016, pp. 39-59.

${ }^{9}$ Akhmad Hidayatullah Al Arifin, "Implementasi Pendidikan Multikultural dalam Praksis Pendidikan di Indonesia", Jurnal Pengembangan Pendidikan: Fondasi dan Aplikasi, Vol. 1, No. 1, June, 2012, p. 72-82. DOI: http://dx.doi.org/10.21831/jppfa. v1i1.1052

${ }^{10}$ Egi Sukma Baihaki, "Strengthening Bhinneka Tunggal Ika as An Identity and Unifier of The Nation: Realizing a Peacful Islam and Statehood Harmonization", Addin, Jurnal Sekolah Tinggi Agama Islam Kudus, Vol. 11 No. 1, February 2017, pp. 55-75. DOI: http://dx.doi.org/10.21043/addin.v11i1.1965

${ }_{11}$ Dendy Sugono, Kamus Besar Bahasa Indonesia Pusat Bahasa Edisi Keempat, Jakarta: PT. Gramedia Pustaka Utama, 2014, $7^{\text {th }}$ edition, p. 1208. 
other by shaking bands. ${ }^{12}$ The wordsalaamin arabicis السَّلامِ As-Salâm, whileuttering salam in Arabic verbis سَتَلَّمَ - يُسَلِّمْ

In English, salaam means peace, or greetings, while bersalaman means to greet, or to shake hands. ${ }^{14}$ Peace literally means a situation or a period of time in which there is no war or violence in a country or an area. ${ }^{15}$ It can also means a state of calm and quiet, atau freedom from disturbing thoughts or emotion. ${ }^{16}$

The meaning of salam in Kamus Besar Bahasa Indonesia (Big Dictionary of Indonesian Language), which is the same meaning as salaam greeting in Islam, سَاََامٍ عَلَيْكُمْ salâmun 'alaykum, ${ }^{17}$ shows that the word salam in Bahasa Indonesia originated from Arabic. According to Dellis Pratika, Bahasa Indonesia is a high-class Malay language deliberately chosen as the national language against colonialism, while Malay itself is heavily influenced by Arabic. ${ }^{18}$ The existence of Arabic language in the archipelago was also highlighted by Ismail Suari Wekke, who found that although in areas where Muslims are a minority, such as in Papua, Islamic boarding schools (pesantren) there still prioritize learning Arabic with traditional methods of pesantren in general. $^{19}$

\footnotetext{
${ }^{12}$ Ibid.

${ }^{13}$ Achmad Warson Munawwir, Al-Munawnir: Kamus Indonesia - Arab, Surabaya: Pustaka Progressif, 2007, p. 750

${ }^{14}$ John M. Echols and Hassan Shadily, An Indonesian-English Dictionary, Jakarta: PT. Gramedia Pustaka Utama, 2006, Third Edition, p. 475

${ }_{15}$ Margaret Deuter (managing editors), Oxford Advanced Learner's Dictionary of Current English, Oxford: Oxford University Press, 2015, ninth edition, p. 1097.

${ }^{16}$ Merriam-Webster, Inc., Merriam-Webster's Dictionary and Thesaurus, Updated Edition, Massachusetts: Merriam-Webster, Inc., 2014, p. 609.

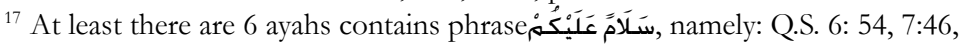
13: 24, 16:32, 28: 55, and 39: 73 .

${ }^{18}$ Dellis Pratika, "The Existence of Indonesian Language: Pidgein or Creole", Journal on English as a Foreign Languge, IAIN Palangkaraya, Volume 6, Number 2, September 2016, (DOI: http://dx.doi.org/10.23971/ jefl.v6i2.397),pp. 83-99.

${ }^{19}$ Ismail Suardi Wekke, "Arabic Teaching and Learning: A Model from Indonesian Muslim Minority”, Procedia - Social and Behavioural Sciences,
} 
According to Ibnu Manzhur, السَّلِِلِّ in Arabic means the affairs of every blessed person, and if someone says salaam to others, then the intention is to eliminate hostility and sins between them. Furthermore, Ibn Manzhur said that Allah ta'ala requires Muslims through Islam to give birth to peace and Muslims are ordered to spread it. Uttering salaam contains the meaning of "peace be upon youand nobody fools you". This is a true and sincere word, there is no game in it. ${ }^{20}$

To sum up, the meaning of the word salaam is twofold, namely respectful utterance and peace with deep meaning, no duping, no fraud, no injustice and no violence. Body language representing greetings as well as gestures of peace are manifested by shaking hands

In Islam, the word السَّلاِطُ is of utmost importance. The word Islam in fact originates from the same rootword of sal

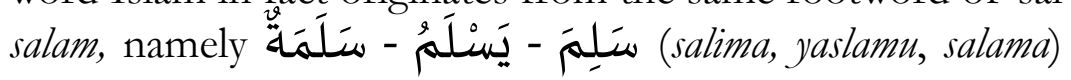
which means greet, keep from harm, protect. ${ }^{21}$ Ina Saheeh Bukhari hadeedth number 6230 it is mentioned that Rasulullah p.b.u.h emphasizedthat As-Salaam one of the names of Allah S.W.T., السَََّلَُُ As-Salâm, The Source of Peace. ${ }^{22}$ This is also mentioned in the Quran, surah Al-Hasyr: 23.

Salvation or peace is a goal of every human being, not only those who embrace Islam. Robert Jackson and Satoko Fujiawara argued that religious education has a great potential for peace education and academics should further elaborate

Number 191, 2015, (DOI: https://doi.org/10.1016/j.sbspro.2015.04.236 ), pp. 286-290. 22nd, 2018.

${ }^{20}$ Al-Imâm Ibn Manzûr, Lisân al-'Arab, Kairo: Dâr al-Hadîts, 1434, Vol. 4, p. 660.

${ }^{21}$ https://www.almaany.com/ar/dict/ar-en/سلم accessed on January

${ }^{22}$ Abû 'Abdillâhi Muhammad bnu Ismaîl al-Bukhârî al-Ja'fî̀, Sabîhu al-Bukhârî, Kitab al-Isti'dzânu, Kairo: Syarikah al-Qudsi, 2014, p. 1259. 
this potential. ${ }^{23}$ In line with this, Steven Slade raised in his thesis that post-conflict in Rwanda, needs to invest in peace education curriculum especially among children. ${ }^{24}$

Elly Malihah also discusseses the importance of efforts to reduce conflicts among university studentswhich emerge from their differences, and this requires the development of models to anticipate such possible conflicts. ${ }^{25}$ The concern for peace was also apparent at the backdrop of the evolution of the League of Nations which was established in 1919 to become the United Nations in $1945 .^{26}$ The change was related to the desire to form a more powerful institution to create peace in the world. ${ }^{27}$

In the Quran Surah 12:25, it is mentioned that Allah S.W.T. as the Creator invites man to dâr al-salâm, the land of salvation, and this is also raised in the Quran Surah 12: 25. The vital value of salvation and peace in Islam is also indicated in the Quran Surah 5:34, where Allah S.I.T., says that killing one soul for no justified reason equalsto killing all human beings, and vice versa, saving one soul equals to saving all humanity.

\section{Islamic ruling on Salaam}

The following is a discussion of some of Islamic rules that underlie the ordinance of salaam:

${ }^{23}$ Roberts Jackson and Satoko Fujiwara, "Towards Religious Education for Peace", British Journal of Religious Education, Volume 29, Number 1, January 2007, pp. 1-14.

${ }^{24}$ Steven Slade, "Peace Education for Children in Post-Conflict Societies as Part of a Conflict Transformative Approach: Theory in Practice?" Thesis, Malmo University.

${ }^{25}$ Elly Malihah, at all, "Teaching Conflict Resolution through General Education at University: Preparing Students to Prevent or Resolve Conflicts in a Pluralistic Society", Asian Social Science, Volume 11, Number 12, 2015, pp. 353-361

${ }^{26}$ Source: http://www.un.org/en/sections/history/history-unitednations/ accessed on January 21th, 2018.

${ }^{27}$ Leland M. Goodrich, "From League of Nations to United Nations", International Organization, Vol. 1, No. 1, February, 1947, The MIT Press, pp. 3-21. 
Answering salaam with more complete or at least the same degree of salaam. This refers toSaheeh Bukhari, hadeeth number 6227 , in which is is mentioned that the angel answered with better salaam to Prophet Adam a.s. ${ }^{28}$

The riding one should greet the one who is walking, and a person on foot should greet the one who is sitting; a smaller group should greet a larger group and the young should greet their elders. This rule is mentioned in Sunan Tirmidhi hadeethnumber $2703^{29}$. Imam Nawawi was of the opinion that this hierarchy is sunnah, and if anyone practices it otherwise it is fine, but it means he leaves behind the more benignact. ${ }^{30}$

It is permissible to say salaam to a beterogen group, as mentioned in the hadeethof Bukhari number 6254. Imam Nawawi argues that this hadeeth, in which it is mentioned that Rasulullah p.b.u.hsaid salaam to a gathering of peoplethat consisted of Muslims and others, can be use as evidence to allow to say salaam to a group in which there are Muslims and non-Muslims. This has been agreed by majority of scholars. ${ }^{31}$

\section{Salaam and seeking permission}

Imam Bukhari in his saheeh book, which is considered the most authentic source of Islamic teaching after the Quran ${ }^{32}$, places hadeeths concerning salaam and its ruling in the Chapter on Seeking Permission. Similarly, in sunan book of Imam Tirmidzi, hadeeths on salaam are placed under the Chapter on Seeking Permission. ${ }^{33}$ The strong link between seeking permission

${ }^{28}$ Abû 'Abdillâhi Muhammad bnu Ismaîl al-Bukhârî al-Ja ‘fî, Sahîhu al-Bukhârî, p. 1258.

${ }^{29}$ Muhammad bnu îsâ al-Tirmidzî, Sunan al-Tirmid ఇ̣̌̂, Riyad: Maktabah al-Ma‘ârif li al-Nasyri wa al-Tawzî’, 1429H., p. 609.

${ }^{30}$ Yahyâ bnu Syarfi al-NawâwîMuhyi al-Dîn Abû Zakariâ, S aḅ̂̄h Muslim bi Syarbi al-Nawâwî, Kairo: Mû́assasah Qartubah, 1412H., Juz 14, p. 200.

${ }^{31}$ Ibid., Juz 12, p. 219.

${ }^{32}$ Subhi al-Sâlih, 'Ulum al-Hadits wa Mustalâbuhu, Beirut: Dâr al-'Tlm li al-Malâyîn, 1984, p. 396

${ }^{33}$ Muhammad bnu Îsâ al-Tirmidzî, Sunan al-Tirmidæ̣̌̂, pp. 605-615. 
and salaam greeting is also evident in the Quran Surah 24:27, in which Allah S.W.T. says to the believers not to enter houses other than their own house without first announcing their presence and invoke salaam upon the folk thereof. This is understandable because when someone asks permission to enter a house, he should begin by greeting the house' inhabitants. The greeting also becomes a gesture or a sign of notification of the coming or the presence of the person who utters it.

Seeking permission by uttering salaam is only allowed three times. If there is no response, the person seeking permission should leave. The goal is to keep the eyes and ensure privacy of the in habitants of the place being visited. This is mentioned in hadeeths number 6238-6242 $2^{34}$. Thesehadeethsprovide a lesson that prohibits someone from spying or wanting to know the affairs of people who have nothing to do with him. Ibn Hajar al-Asqalani explained that thesehadeethsare not only intended for foreigners but they also apply to fellow family members who have reached puberty. ${ }^{35}$

In spite of having been invited to come, permission should still be sought before entering the place of the person who invites. This is mentioned in Saheeh Bukhari hadeeth number $6246 .{ }^{36}$ This would allow the invitor to ensure that everything is ready to receive his guests. Ibn Hajar al-Asqalani explains thatthe advice for invitees to seek permission when they arriveat the location where they are invited holds precautionary values. However, according to al-Asqalani, Imam Bukhari also raisesa hadith from Qatadah that the invitation can be regarded as a permission. Imam al-Asqalani then compromises both of these

${ }^{34}$ Abû 'Abdillâhi Muhammad bnu Ismaîl al-Bukhârî al-Ja'fî, Sabîhu al-Bukhârî, pp. 1260-1261.

${ }^{35}$ Ahmad bnu 'Alî bnu Ja'far al-Asqalânî, Fatbu al-Bârî, Kairo: Dâr al-Kutub alSalafiyyah, 2015, Vol. 11, p. 25.

${ }^{36}$ Abû 'Abdillâhi Muhammad bnu Ismaîl al-Bukhârî al-Ja'fî, Sabîhu al-Bukhârî, p. 1262. 
hadeeths by saying that if the time interval between the call and the imminent arrival, it is acceptable to enter without permission. ${ }^{37}$

Seeking permission is not limited to a visit to a house or place of a person. This rule would also apply to the use of public facilities. This value is contained in the prohibition of sitting by the roadside, as mentioned in the hadeeth number 4815 of Sunan Abu Dawood. ${ }^{38}$ Imam An-Nawawi saiys that the content of this hadeeth is very deep in its meaning. The wisdom of such prohibition is to avoid people gathering by the roadsides to gossip and harass road users; and to ensure the road is clear for road users. Imam An-Nawawi also says that a well-known person feared by society should avoid sitting on the street as it would make road users to be reluctant to pass by. ${ }^{39}$

\section{Peace values in the rules concerning salaam}

Below are some values that can be derived from salaam greeting and the rules associated with it:

First, good acknowledgment and appreciation to opposite speaker. This value is contained in the rules of returning salaams, i.e. with a better salaam or at least the same degree. It teaches the value of gratitude and appreciation to the good deeds of others. Abiding by this rule will bring a sense of peace and serenity because it implies a recognition of the existence and goodness of others.

Second, good deeds should be directed at all people equally, regardless of their race, religion or group. Differences in society can be bridged by the conduct of seven major social practices as mentioned in hadeedth

\footnotetext{
${ }^{37}$ Ahmad bnu 'Alî bnu Ja'far al-Asqalânî, Fathu al-Bârî, Vol. 11, pp. 31-32.

${ }^{38}$ Muhammad bnu Ahmad al-Dzahâbî, Sunan Abî Dâwud, Riyad: Maktabah alMa ârif li al-Nasyri wa al-Tawzî‘, 1428H., p. 873.

${ }^{39}$ Yahyâ bnu Syarfi al-NawâwîMuhyi al-Dîn Abû Zakariâ, $\underline{\text { Sahîh }}$ Muslim bi Syarbi al-Nawâwî, Juz 14, p. 145
} 
number 6235 of Saheeh Bukhari ${ }^{40}$, namely: visit the sick, attend funerals, pray for the one who sneezes, help the weak, help the oppressed, spread salaam, and fulfill the oath. Muslims are encouraged to do these good deeds to anyone.

Common good deeds directed at anyone without dscrimnations are also reinforced in hadeedth number 6236 of Saheeh Buchari, in which the Prophet p.b.u.h said that one of the things that is included in the vertue of Islam is to say salaams to both known and unknown and feed (the poor). This practice will bridge the gap between the rich and the poor, bringing a sense of peace because it develops a sense of trust among different people in society. These good qualities are the character of the believers as described by Allah S.W.T. in the Quran Surah 70: 23-33 and Surah 23: 1-11.

Third, the majority or stronger group should protect the minority or the weak. This value is contained in the hadeeth about the rules of which party should give salaam first. For example, hadeeth number 6232 states that the riding one should greet the one who is walking; and number 6233 states that a person on foot should greet the one who is sitting. Al-Utsaimin says that this hierarchy is concerned with the position of the greeters: the one on a vehicle is in a higher position than the one on foot; the one who walks is higher than the one who are sitting. ${ }^{41}$

Fourth, guarantee and respect of the rights of individual privacy. This value is contained in the hadeedth of salaam rules related to seeking permission. One should not spy, peek, and must respect the privacy of the personhe visits. This will prevent the spread of negative issues to develop in the community arising from disclosure of someone's

${ }^{40}$ Abû 'Abdillâhi Muhammad bnu Ismaîl al-Bukhârî al-Ja 'fî, Sahîhu al-Bukhârî, p. 1260.

${ }^{41}$ Muhammad Sâlih al-'Utsaymîn, Syarbu Riyâdu al-Sâlibîn, Juz 4, pp. 408-409. 
private affairs that should not become a public consumption. A sense of security that emerges from the assurance that individual privacy will not be infringed, will contribute to the maintenance of peace.

Fifth, guarantee of the comfort and safety of the public. This value is contained in hadeethBukhari number 6229 ${ }^{42}$, in which the Prophet p.b.u.h forbids sitting on the roadside; and if one should still be on the roadiside, then he must make sure that he does not infringe the rights of the road users. These rights include the rights of not being observed or disturbed, receivinga reply when saying salaam, being invited to command the good and forbid the evil. This hadeedth contains a lesson to keep every facility or public facilities to be used properly by the public. Therefore, it is not allowed to close a road for the benefit of a small number of people and disrupt the interests of more people.

Another hadeeth which also contains the pillars to ensure this public convenience is hadeedth number $6269^{43}$ in which Rasulullah p.b.u.h issues a prohibition of asking someoneto get up from his seat so that the person who asks can use the seat. This implies a prohibition of seizing people's from hi place, as well as a prohibition to interrupt a queue.

Respect of public safety and convenience is also contained in the hadeeth Bukharinumber 6293 and $6294^{44}$. Rasulullah p.b.u.h orders to extinguish the fire before going to sleep, and warned that the fire is a dangerous enemy. In this command there is a lesson to consider and anticipate the possibilities of something that can threaten the safety, not only of oneself but also of others. In addition, hadeedth number 6295 of shahee Bukhari mentions

${ }^{42}$ Abû 'Abdillâhi Muhammad bnu Ismaîl al-Bukhârî al-Ja'fî, Sabîhu al-Bukhârî, p. 1259.

${ }^{43}$ Abû 'Abdillâhi Muhammad bnu Ismaîl al-Bukhârî al-Ja'fî, Sabîhu al-Bukhârî, p. 1268.

${ }^{44}$ Ibid., p. 1271. 
about the command to lock the door before going to bad ${ }^{45}$. This suggests a preventive value; itprovides a teaching of the need to vigilant and does not give an opportunity to people who have diseases in his heart to commit evil deeds.

Al-Utsaimin also links the rules of salaam with public comfort. This is exemplified by the advice to the riding one to greet the one who is walking. According to him, the greeting of salaam should not be replaced with honking. Al-Utsaimin adds his explanation that when saying salaam, one should also avoid disturbing those who are sleeping by lowering his voice as such only the person to whom he gives salaam can hear. ${ }^{46}$

This above discussion shows that salaam and its rules are quite comprehensive in providing teaching of how to maintainpublic order and comfort. If safe and comfortable circumstances can be maintaine, the sense of peace can be eventually enjoyed by everyone.

\section{Sixth, prioritising peace, setting aside hostilities.} This can refer to the hadeedth regarding the primacy of the person who first greets the one he is hostile to. It is also reflected the hadeethnarrating that the Prophet p.b.u.h didnot return the evil words of the Jews with evil words. If these values are embraced in the community, hostilities that may already exist can be prevented from developing into open conflicts.

\section{Conclusion}

Maintaining peace is considred vital in Islamic teaching, and history has proven that Islam is a regligion that can bring about peace in society. Islam's promotion of peace was also exemplified by the Messenger of Allah in the Hudaibiyah treaty, for which the Messenger fulfil the request of the

\footnotetext{
${ }^{45}$ Ibid., p. 1268.

${ }^{46}$ Muhammad Sâlih al-'Utsaymîn, Syarbu Riyââlu al-Sâlihîn, Juz 4, p.404.
} 
Quraish to remove the mention of Muhammad Rasulullah and replace it with Muhammad bin Abdullah, and the Messenger of Allah. ${ }^{47}$

Muslims as the majority of people have been proven to be the guardian and spreader of peace amid the diversities in the archipelago. One good example is the humble attitude of the Muslim leaders who were the pioneers of the independence of Indonesia during the formulation of the five principles of Pancasila. They accepted the request of a non-Muslim person to deletefrom the first principle of Pancasila the sentence on obligation to enforce the Islamic Shari'a for its adherents. Adian Husaini said that this attitude is a form of immense tolerance of Muslims as the majority at that time to the minority. ${ }^{48}$

The greeting of salaam and the rules associated with it contains values that promote peace. The values lay a strong foundation to spread peace strating from improving daily acts and abiding by the rules concerning public confort and safety and respect to one another. Paece that is established and maintained by and within a small group of people can be developed into peace in a large society. ${ }^{49}$ Soerjono Soekanto says that such a small group of people is very important because it essentially becomes a cell that contributes to the movement of organism called society. ${ }^{50}$ If peace is maintained at the grassroots

${ }^{47}$ Muhammad Said Ramadhan Al-Buthy, Fiqh as-Sirah an-Nabawiyah Ma'a Mujaz. Litârikkh al-Khilâfah al-Râsyidah, p. 513.

${ }^{48}$ Dr. Adian Husaini, Pancasila Bukan untuk. Menindas Hak Konstitusional Umat Islam, Jakarta: Gema Insani, 2009, p.20 and Ahmad Mansur Suryanegara, Api Sejarah, Bandung: Surya Dinasti, 2016, Vol. 2, pp. 169-172.

${ }^{49}$ One of UNESCO's aim is to develop in individuals the skills of interpersonal communication, and to create awareness of the importance of living in harmony with each other. UNESCO, Learning to Live Together in Peace and Harmony, UNESCO Principal Regional Office for Asia \& Pasific, Bangkok, 1988, p. 20.

${ }^{50}$ Soerjono Soekanto, Sosiologi Suatu Pengantar, Jakarta: Rajagrafindo Persada, 1982, pp. $104-145$. 
level, it can then spread to a wider scope and eventually peace can be realized in the archipelago of Indonesia.

The role of Muslims in prioritizing peace in the archipelago is reveaked in the research conducted by Ihsan Ali-Fauzi et al. in cooperation with the Asia Foundation. The researce formulated a map that shows Indonesia has the potentials to produce peaceful actions. ${ }^{51}$ This shows that Muslims with the values contained in their religion, have the potentials to become pioneers to realize and maintain peace in the archipelago.

The values contained in the greeting of salaam and its rules need to be further developed through the educational process. This is in synergy with the general goal of multicultural education that Rustam Ibrahim raised, that is to create a peaceful and harmonious life in the diverse Indonesian archipelago. ${ }^{52}$

${ }^{51}$ Ihsan Ali-Fauzi, "Pola-Pola Konflik Keagamaan di Indonesia (1990-2008)", Research report of Yayasan Wakaf Paramadina and The Asia Foudation, Jakarta, 2009, p. v.

${ }^{52}$ Rustam Ibrahim, "Pendidikan Multikultural: Pengertian, Prinsip, dan Relevansinya dengan Tujuan Pendidikan Islam", Addin, Jurnal Sekolah Tinggi Agama Islam Kudus, pp. 129-154. DOI: http://dx.doi.org/10.21043/addin.v7i1.573 


\section{REFERENCES}

Abdurrahman, Dudung. "Multiculturalism in Islamic Civilization During the Classic Period", Addin, Jurnal Sekolah Tinggi Agama Islam Negeri Kudus, Vol. 11, No. 1, February 2017. (DOI: http://dx.doi. org/10.21043/addin.v11i1.2071)

Abî al-Husayni Muslim bnu al-Hajjâr, Al-Imâm. Sabîhb alMuslim, Beirut: Dâr bnu Hazm, 1430 H.

Al-Arifin, Akhmad Hidayatullah. "Implementasi Pendidikan Multikultural dalam Praksis Pendidikan di Indonesia", Jurnal Pengembangan Pendidikan: Fondasi dan Aplikasi, Vol. 1, No. 1, June, 2012. (DOI: http:// dx.doi.org/10.21831/jppfa.v1i1.1052)

al-Asqalânî, Ahmad bnu 'Alî bnu Ja'far. Fathu al-Bârî, Kairo: Dâr al-Kutub al-Salafiyyah, 2015.

Baihaki, Egi Sukma. "Strengthening Bhinneka Tunggal Ika as An Identity and Unifier of The Nation: Realizing a Peacful Islam and Statehood Harmonization", Addin, Jurnal Sekolah Tinggi Agama Islam Kudus, Vol. 11 No. 1, February 2017. (DOI: http://dx.doi. org/10.21043/addin.v11i1.1965)

al-Bukhârî, Abû 'Abdillâhi Muhammad bnu Ismaîl al-Ja'fî. Sabîhu al-Bukbârî, Kairo: Syarikah al-Qudsi, 2014.

al-Buthy, Muhammad Said Ramadhan. Fiqh as-Sirah anNabawijah Ma'a Mujaz Litârikh al-Kbilâfah al-Râsyidah, Damaskus: Dâr al-Fikri, 1991.

Deuter, Margaret (managing editors).Oxford Advanced Learner's Dictionary of Current English, Oxford: Oxford University Press, 2015, ninth edition. 
al-Dzahâbi, Abû DâwudMuhammad bnu Ahmad.Sunan Ab̂̂ Dâwud, Riyad: Maktabah al-Ma'ârif li al-Nasyri wa alTawzî', $1428 \mathrm{H}$.

Echols, John M. and Hassan Shadily. An Indonesian-English Dictionary, Jakarta: PT. Gramedia Pustaka Utama, 2006, Third Edition.

Fauzi, Ihsan Ali. "Pola-Pola Konflik Keagamaan di Indonesia (1990-2008)", Research report of Yayasan Wakaf Paramadina and The Asia Foudation, Jakarta, 2009.

Fuller, Graham E. A World Without Islam, New York: Back Bay Books, 2012.

Goodrich, Leland. "From League of Nations to United Nations", International Organization, Vol. 1, No. 1, February, 1947, The MIT Press.

Husaini, Adian, Dr. Pancasila Bukan untuk Menindas Hak Konstitusional Umat Islam, Jakarta: Gema Insani, 2009.

Ibn Manzûr, al- Imâm. Lisân al-'Arab, Kairo: Dâr al-Hadîts, 1434.

Ibrahim, Rustam. "Pendidikan Multikultural: Pengertian, Prinsip, dan Relevansinya dengan Tujuan Pendidikan Islam", Addin, Jurnal Sekolah Tinggi Agama Islam Kudus, pp. 129-154. DOI: http://dx.doi.org/10.21043/ addin.v7i1.573

Jackson, Roberts, and Satoko Fujiwara. "Towards Religious Education for Peace", British Journal of Religious Education, Volume 29, Number 1, January 2007.

Malihah, Elly at all. "Teaching Conflict Resolution through General Education at University: Preparing Students to Prevent or Resolve Conflicts in a Pluralistic Society", Asian Social Science, Volume 11, Number 12, 2015. 
Merriam-Webster, Inc. Merriam-Webster's Dictionary and Thesaurus, Updated Edition, Massachusetts: MerriamWebster, Inc., 2014.

Munawwir, Achmad Warson. Al-Munawwir: Kamus IndonesiaArab, Surabaya: Pustaka Progressif, 2007.

Murphy, Tim Wallace. What Islam Did for Us, Understanding Islam's Contribution to Western Civilization, London: Watkins Publishing, 2006.

al-Nasâî,Ahmad bnu 'Alî. Sunan Nasâî. Riyad: Maktabah alMa'ârif li al-Nasyri wa al-Tawzî', 1429H.

al-Nawâwî, Yahyâ bnu Syarfi al-Nawâwî Muhyi al-Dîn Abû Zakariâ. Sabzîh Muslim bi Syarbi al-Nawâwî, Kairo: Mûassasah Qartubah, 1412H.

Pratika, Dellis. "The Existence of Indonesian Language: Pidgein or Creole", Journal on English as a Foreign Languge, IAIN Palangkaraya, Volume 6, Number 2, September 2016, (DOI: http://dx.doi.org/10.23971/ jefl.v6i2.397).

Sâlih, Subhi.'Ulum al-Hadits wa Mustalâhubu, Beirut: Dâr al'Ilm li al-Malâyîn, 1984.

Slade, Steven. "Peace Education for Children in PostConflict Societies as Part of a Conflict Transformative Approach: Theory in Practice?" Thesis, Malmo University.

Soekanto, Soerjono. Sosiologi Suatu Pengantar, Jakarta: Rajagrafindo Persada, 1982.

Sugono, Dendy. Kamus Besar Bahasa Indonesia Pusat Bahasa Edisi Keempat, Jakarta: PT. Gramedia Pustaka Utama, $2014,7^{\text {th }}$ edition. 
Sukoco. "Kebijakan Pendidikan Multikultural di Indonesia", Majalah Ilmiah Pawiyatan, Special Edition, Vol. XXII, No. 2, Juli 2015.

Suryanegara, Ahmad Mansur. Api Sejarah, Bandung: Surya Dinasti, 2016.

al-Tirmidzî, Muhammad bnu Îsâ.Sunan al-Tirmidžl, Riyad: Maktabah al-Ma'ârif li al-Nasyri wa al-Tawzî', 1429H.

UNESCO Principal Regional Office for Asia \& Pasific, Bangkok, 1988

al-'Utsaymîn, Muhammad Sâlih.Syarbu Riyâdu al-Sâlibîn, Riyad: Madâr al-Watan li al-Nasyrah, 1426.

Wekke, Ismail Suardi. "Arabic Teaching and Learning: A Model from Indonesian Muslim Minority", Procedia - Social and Behavioural Sciences, Number 191, 2015, (DOI: https://doi.org/10.1016/j.sbspro.2015.04.236 ).

Wicaksono, Juniaris Agung. "Konsep Pendidikan Multikultural dalam Kebijakan Publik di Indonesia", An-Nuha, Jurnal Sekolah Tinggi Agama Islam Madiun, Volume 3 Number 1, July 2016.

\section{Internet:}

http://bphn.go.id

https://www.almaany.com 
Nesia Andriana

Halaman Ini Tidak Sengaja Untuk Dikosongkan. 